\title{
Determine optimal areas for the design of diesel, wind, biomass, photovoltaic and non- volatile power stations for domestic use
}

\author{
Farhad Farahmand * \\ Department of Electrical Engineering, Neyshabour Branch, \\ Islamic Azad University, Neyshabur, Iran. \\ Ali Asghar Shojaei \\ Department of Electrical Engineering, Neyshabour Branch, \\ Islamic Azad University, Neyshabur, Iran. \\ dahraf_farhad@yahoo.com
}

\begin{abstract}
Today, the use of new energy as a source of dispersed sources of production has grown dramatically throughout the world. This article aims to study the technical and economic parameters of a diesel, windy, photovoltaic, biomass and battery combination system for a large indirect electricity supplier in eastern of Iran. As a case study, the feasibility of a hybrid system for meeting the needs of the population of the population with a load factor of 0.25 was investigated. This is designed to reduce system costs over its 20-year life span. Homer's software is designed to model system performance and identify its optimal areas based on technical, economic, and environmental analysis. Finally, the proposed model is simulated with the help of Homer software along with the anomaly, radiation, fuel prices and biomass cost of the eastern regions of Iran. By comparing the results, it can be concluded that with the proper design of dispersed production resources, a significant amount of costs can be reduced and the use of renewable energy is economical.
\end{abstract}

Key words: Renewable energies, Wind energy, Biomass, photovoltaic, Homer.

\section{Introduction}

Power supply developed more than other energies. The world's generation of electricity has increased from 17573.3 million megawatts in 2004 to $23,536.5$ million megawatts in 2014, with an average annual growth of $3 \%$. The share of fossil fuels, hydrocarbons, non-nuclear hydrocarbon and solar energy (including solar cells, solar thermal, windy, geothermal and tidal) in world electricity production is $68 \%, 16.5 \%, 11 \%$, and $3 \%$. (International Energy Agency). In 2014, nearly 271.2 million MWh of electricity was generated in Iran, accounting for $94 \%$ of fossil fuels with a $5 \%$ share of hydrocarbon and $0.7 \%$ of water, and the rest of nonaqueous sources used to generate electricity in Iran which makes up a significant amount. The average annual growth rate of electricity generation in Iran is $5.7 \%$, which is twice the global average growth rate. This rapidly increasing energy consumption in Iran has reduced the export of crude oil and natural gas to meet domestic demand and has had severe effects on the developing country's economy. At the end of the 20-year-old (20252020) program, 2000 megawatts of electricity should be generated from non-renewable resources with government and private sector investment of 3 billion dollars. In addition, using vast resources of fossil fuels such as crude oil and natural gas, Iran is rich in renewable resources such as wind and solar energy. The nominal wind capacity in Iran is estimated at 60,000 megawatts, potentially capable of generating 18,000 megawatts of electricity (British Energy 2014). Iran is located in the world's solar belt, which has 300 sunny days in one year, which gains and enjoys two-thirds of its territory in the medium-range solar radiation, which is estimated at 5.4$5.5 \mathrm{kV} / \mathrm{m} 2$ per day. (Suna). A hybrid energy system is defined as a system in which the difference in ENT energy resources (solar, wind, blue, diesel generator, etc.) is used to be used to supply energy demand. The most important advantage of hybrid systems is that system reliability improves when all kinds of energy resources are used together. In addition, reducing the cost of renewable energy technologies as a result and accelerating them will make them more attractive to investors. We can point to the availability of this energy in a remote area and a village in which other sources of energy, such as electricity and natural gas, are not available, as another point. Homer is used to design a hybrid energy system for the eastern parts of Iran They assessed the feasibility of different diesel systems - different diesel and network systems (Prasetyaningsari et al). Study of the electrical energy shows a moderate hotel in Kish Island, southern Iran, use renewable energy sources of wind and sun. They used the Homer model and showed that it was the most economical diesel battery, but suggested that the hybrid diesel-diesel system was superior to the diesel battery system. It releases carbon dioxide emissions by 14\% less (Kumar et al 2014). A mathematical software code used to simulate and optimize a hybrid power generation system containing photovoltaic samples, wind turbines, biomass, diesel and a battery. The optimal 
number of photovoltaic samples, wind turbines, biomass, diesel, as well as stored batteries was determined and the results were confirmed by Homer software. The main problem of renewable energy systems is the excessive dependence of these systems on environmental conditions, which change with time. One way to overcome this problem is to combine these energy sources with traditional energy systems using the strengths of an energy source to balance the weaknesses of other energies. A wind-generated solar power system with a diesel generator and power storage or network connection can provide such reliable electricity supplier (Elghitani, F. et al). In such a system, the main challenge is to obtain the desired size and compute components to meet the demand for the electric charge at minimum cost. This paper examines the feasibility of using a hybrid power generation system for large electricity consumers in eastern Iran. The HOMER Pro software is used to simulate and obtain optimal components compatibility for our study. Separated systems from the network with battery storage were investigated. Then, the financial and environmental issues of various items such as cost of electricity (COE), net present value (NPV), internal rate of return (IRR), combustible particles and greenhouse gas emissions are discussed. The effects of uncertainty on load demand and annual change in power consumption are discussed.

Modeling and simulating system operation

In this section, the relations governing the studied system will be examined. Also, to simulate the system, oneyear courses are divided into one-hour intervals, and simulations are run for an hour.

Solar Cell Equations

The maximum solar cell (PV) output power in day $i$ and at $t$ is calculated from equation (1).

$$
\begin{aligned}
& F_{U}^{t}(t)=N_{S} N_{F} V_{O C}^{t}(t) I_{S G}^{t}(t) P P^{t}(t)
\end{aligned}
$$

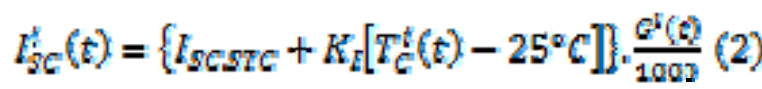

$$
\begin{aligned}
& V_{Q C}^{*}(t)=V_{Q C S T C}-K_{W}^{*}, T_{C}^{*}(t) \\
& T_{c}^{t}(t)=T_{A}^{t}\left(t_{j}^{3}+\frac{N \operatorname{COV}^{2}-2 \mathrm{U}^{\mathrm{V} C} \mathrm{C}}{800} \cdot G^{t}(t)\right.
\end{aligned}
$$

In which, $N_{S}$ and $N_{p}$, respectively, are the number of series cells and parallel solar cells and also in aforementioned equation $V_{\varrho}^{b}(\mathrm{t})$ open circuit voltage $(\mathrm{V}) \cdot(\mathrm{t}), \mathrm{I}_{\mathrm{sc}}^{\mathrm{i}}$ Short circuit current $(\mathrm{A}), \mathrm{FF}^{\mathrm{l}}(\mathrm{t})$ Coagulation factor, $I_{\text {SCSTC }}$ Short circuit current in standard (A), $K_{I}$ Short circuit current temperature coefficient ${ }^{\circ} \mathrm{C}(\mathrm{A}), \mathrm{G}^{\mathrm{I}}$

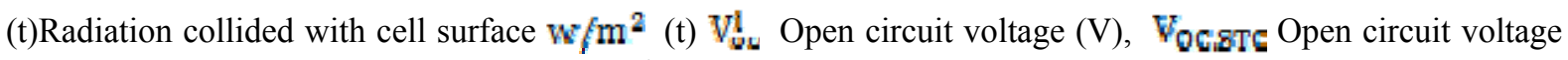
under standard conditions $(\mathrm{V}), \mathrm{K}_{\mathrm{V}}$ Open circuit voltage coefficient ${ }^{\circ} \mathrm{C}(\mathrm{A} /)$, (t) $\mathrm{T}_{\mathrm{A}}^{\mathrm{i}}$ temperature $\left({ }^{\circ} \mathrm{C}\right)$ and NCOT The nominal temperature is cell function. The number of series cells is calculated from equation (5).

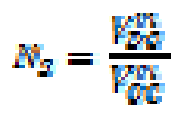

$V_{Q C}^{W}$ is Maximum input voltage of the battery chargers and $V_{\mathscr{C}}^{W}$ is maximum open circuit voltage of solar cells.

\section{Equations for wind units}

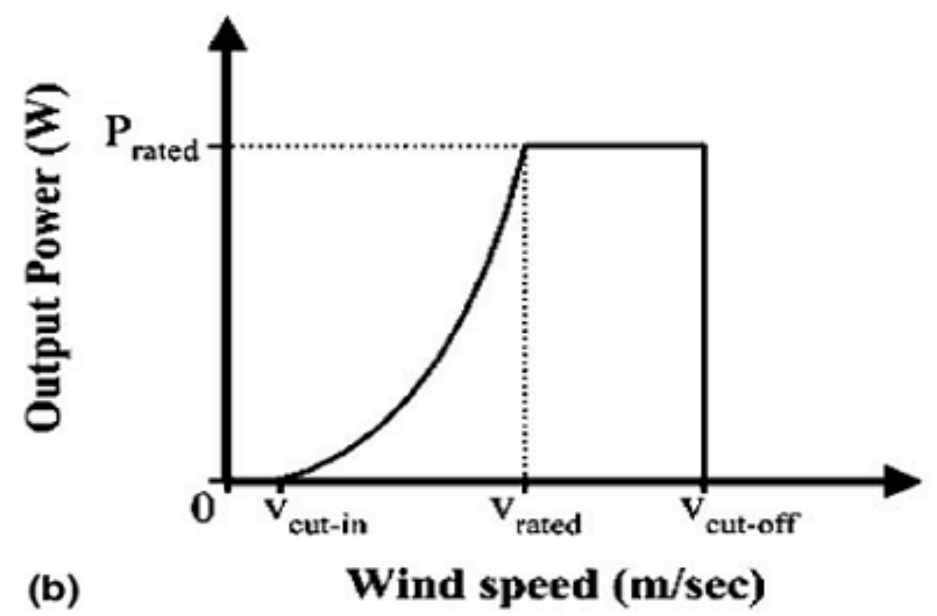

Figure 1: Power characteristic in terms of wind speed in wind unit 
According to Fig. 1, the output power of a wind unit is related to the wind speed and is obtained from equation (6).

$$
\begin{gathered}
P_{W 6}^{i}(t)=P_{1}+\left[V^{i}(t)-v_{1}\right] \cdot \frac{P_{2}-P_{1}}{v_{2}-v_{1}} \\
v_{1}<v^{i}(t)<v_{2}
\end{gathered}
$$

Which $P_{W G}^{i}(\mathrm{t})$ is the battery bank of the wind turbine at $\mathrm{I}$ th day and at $\mathrm{t}$ th hour (w). $\left(\boldsymbol{P}_{1} \cdot v_{1}\right)$ and $\left(P_{2} \cdot \mathfrak{v}_{2}\right)$ are speed and power of wind turbines. The amount of wind speed depends on the height of the turbine installation and is obtained from equation (7).

$$
v^{i}(t, h)=v_{r \in f}^{i}(t) \cdot\left(\frac{\hbar}{r \in f}\right)^{2}
$$

Which $\left(v^{i}(c h)\right.$ is Wind speed in turbine, $v_{r \in f}^{i}(\mathrm{t})$ is base speed value and $h_{r \in f}$ is base height. A fixed term called power law, which is set to between $\frac{1}{4} \leq \frac{1}{7}$

Figure 1: Power characteristic in terms of wind speed in wind unit Calculations of the battery's bank According to the specifications of the battery banks, the bank used in this model is only allowed to discharge $80 \%$. This value depends on the discharge depth determined by the system designer. The minimum capacity of the battery during the discharge process is obtained from equation (8).

$$
C_{M I N}=(1-D O D) \cdot C_{n}^{*}
$$

In the above equation

$\mathbf{C}_{\mathbf{m}: \mathbf{n}}$ The least the capacity of the battery during discharging

DOD :Maximum discharge depth

$\mathrm{C}_{\mathrm{n}}$ Battery Name Capacity

The amount of battery capacity is time-dependent and varies over time in accordance with (9).

$$
\begin{aligned}
& C^{i}(t)=C^{i}(t-1)+n_{D} \frac{P_{L}^{t}(t)}{V_{E U S}} . A t \\
& C^{i}(24)=C^{i+1}(0)
\end{aligned}
$$

In the above relationship

$\mathrm{C}^{\mathrm{j}}(\mathrm{t})$ and $\mathbf{C}^{\mathrm{l}}(\mathrm{t}-1)$ respectively, the available capacity of the battery (Ah) at time $\mathrm{t}$ th and 1-t from day $\mathrm{i}$ th.

$\mathrm{N}_{\mathrm{B}}$ Battery efficiency

$\mathbb{P}_{B}^{1}(t)$ Battery power input / output power

$V_{\text {Dug }}$ DC busbar voltage

$\Delta$ t Simulation step

$$
n_{B}^{S}=\begin{gathered}
v_{B U S} \\
v_{B}
\end{gathered}
$$

The number of series batteries is also obtained from equation (11).

Which we have:

$n_{B}^{\Sigma}$ This is the number of batteries in the series

$V_{B}$ The voltage of each battery 


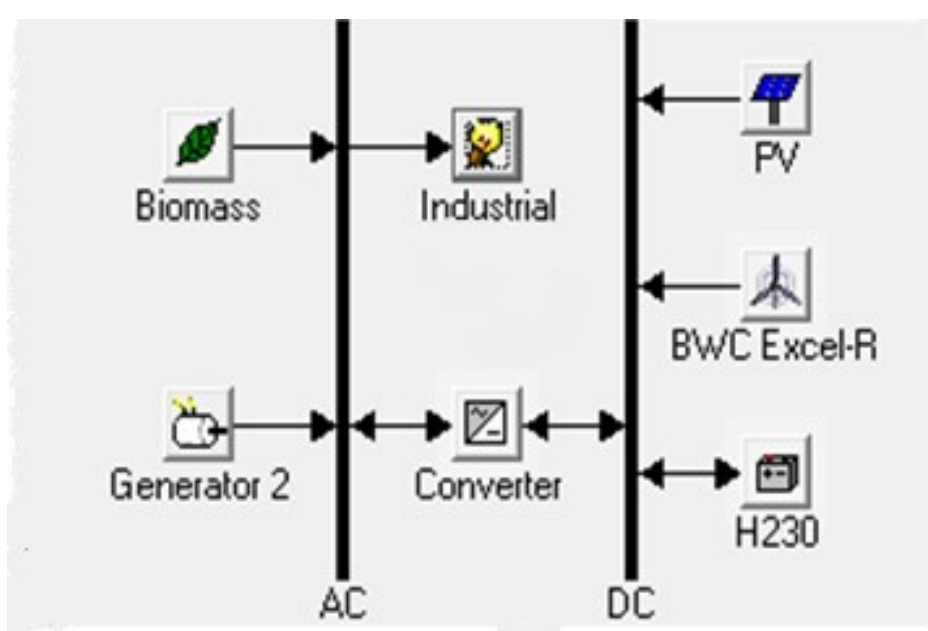

Figure 2: Combined power generation system

\section{1-1 Calculation of initial costs and installation}

The initial cost and installation of the system is a function of the following parameters:

$$
\begin{array}{r}
(C \& I)=\frac{T I C \text { per } \mathrm{kW} \times C R F(d, n)}{8760 \text { hours per year } \times \text { CF }} \\
C R F \quad(d, n)=\frac{d(1+d)^{n}}{(1+d)^{n}-1}
\end{array}
$$

$\mathrm{CF}=$ Number of days of the year * Hours per day /Hours of work throughout the year (14) Which we have:

CRF Coefficient of restitution finance

d Interest rate

$n$ Service life

TIC Total installed cost:

CF Coefficient of performance:

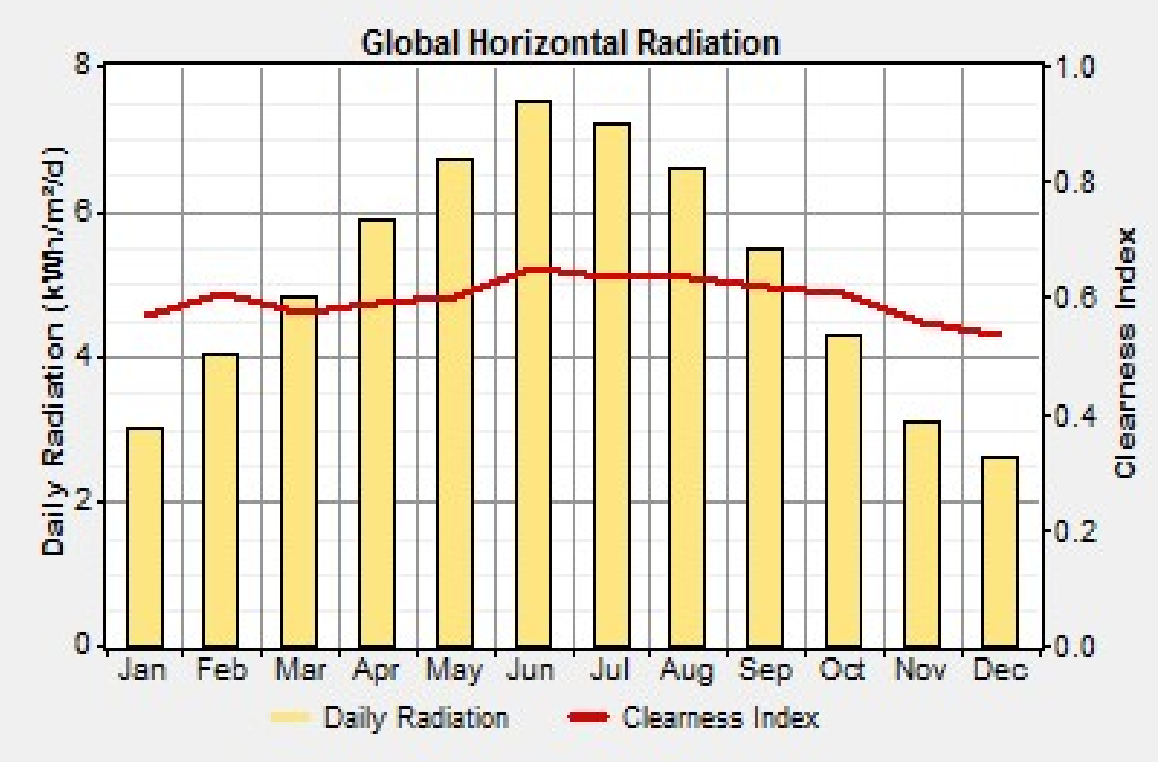




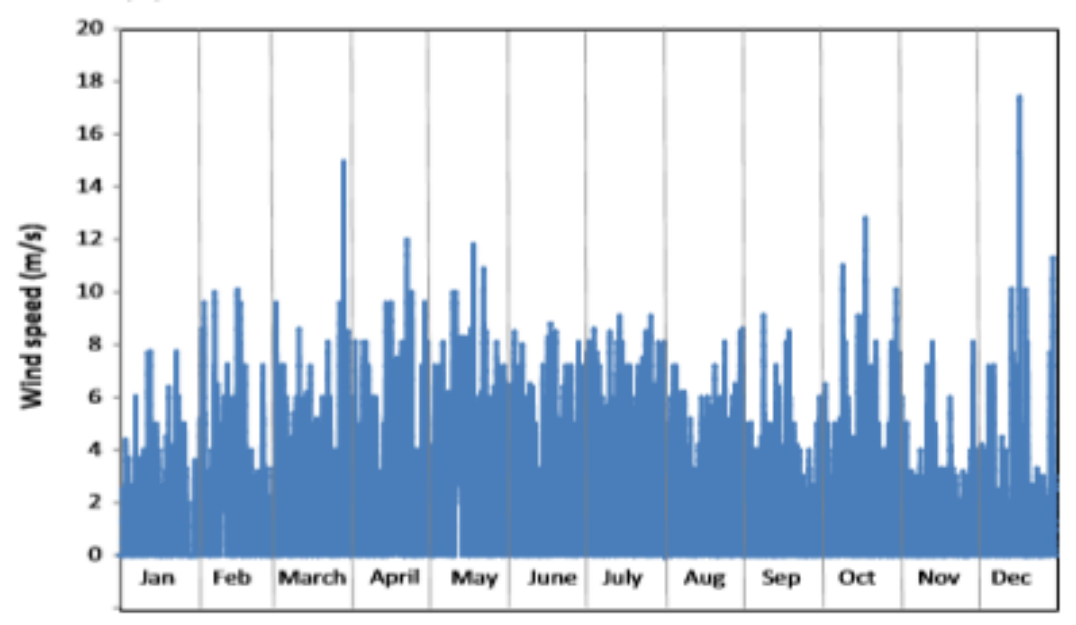

Figure 3: The amount of solar radiation (a) The wind speed in the eastern part (b)

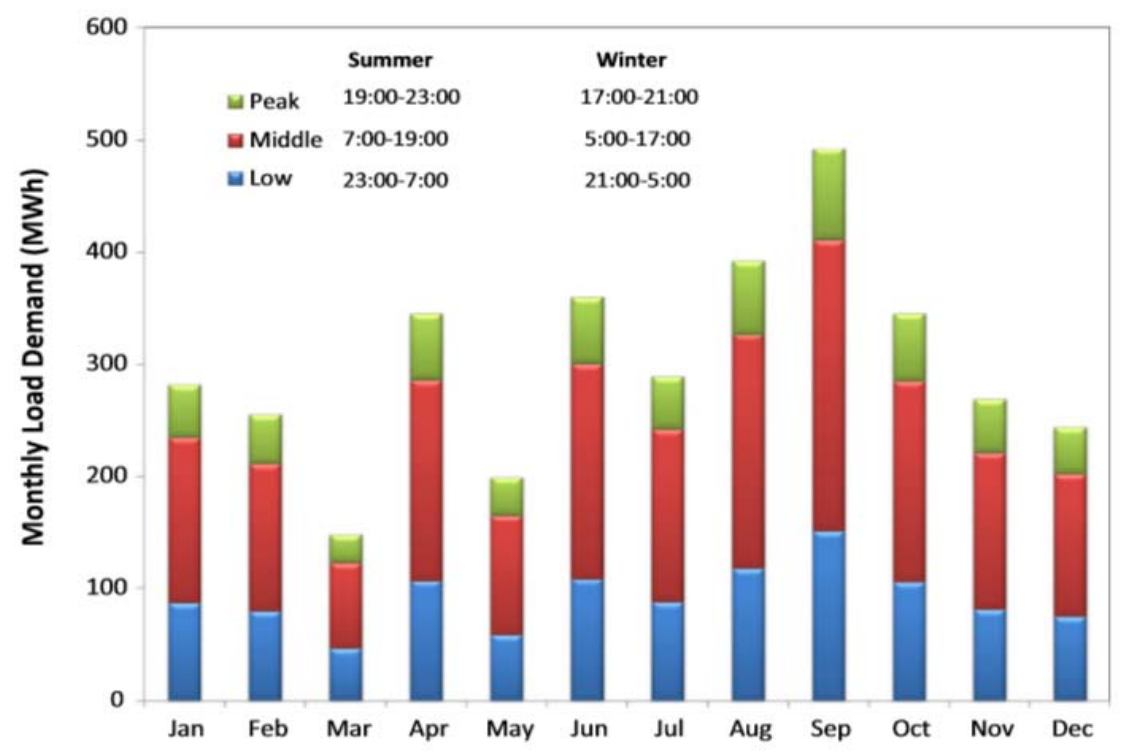

Figure 4: Monthly electricity demand for low, medium and peak hours

\section{Carbon dioxide emissions and carbon taxes}

The emission of carbon dioxide (CO2) in electric hybrid systems is generated by generator and network power consumption. For a generator, annual emissions are calculated by the factor of emission factor by total annual fuel consumption. In a network-connected system, the emission of $\mathrm{CO} 2$ by the net emission factor of the grid (in kilowatt-hours) is evaluated by the emission factor (in g / kilowatt-hour). (Homer Guide) Carbon taxes are a cost that consumers of fossil fuels encounter serious damage when releasing carbon dioxide into the atmosphere. There are no taxes on $\mathrm{CO} 2$ production in Iran, but it can be an incentive to create renewable projects. 
Table 1: Technical Specifications of System Components

\begin{tabular}{|c|l|l|}
\hline diesel generator & $\begin{array}{l}\text { Gasoline consumption at the load Coefficient } \\
\text { of variation }\end{array}$ & 15 liters per hour 1-2-10 \\
\hline Photovoltaic panel & $\begin{array}{l}\text { Type of panel The Level Cleanup Panel } \\
\text { Angle of slope panel }\end{array}$ & $\begin{array}{l}\text { Mono Crystal of Korea / DC 80\% 30 } \\
\text { degree }\end{array}$ \\
\hline Biomass & Minimum load Fuel curve & $30 \% 0.075$ liter per hour \\
\hline Wind Turbine & Type of Turbine Rotor height to ground level & NG8-10KW-VPC 25 meter \\
\hline Battery & Type of Battery & $\begin{array}{l}12 \text { watt jelly 230 ampere Hour from } \\
\text { Hitachi Japan }\end{array}$ \\
\hline Battery Convertor & Converters compatibility & $90 \%$ \\
\hline
\end{tabular}

1-Simulate the system and information required

Each hybrid energy system mainly includes the following: 1. energy generators, such as wind turbines and photovoltaic panels 2 . Non-combustible energy generators, such as diesel generator, biomass, power storage unit, power converter, direct or indirect power, load and network (if available). Figure 2 depicts an overall image for a hybrid energy system. Homer performs three main tasks of simulation, optimization, and sensitivity analysis. It can model the performance of a particular system at any time of the year in order to determine its technical cost and operating costs (Homer's Guide). Homer requires four types of input data, including weather information, load data, system component data, and financial data as follows:

\section{1- Meteorological information}

Birjand is located at 59 degrees 13 minutes longitude and 32 degrees and 53 minutes latitude and at an altitude of 1470 meters above sea level. Solar and wind pattern data for Birjand are presented in Figures 3 (a) and (b), respectively

\section{1-1 Information about the study}

According to the electricity bill, the total demand is $3618 \mathrm{MW}$, with a daily average of $9911 \mathrm{kWh}$, a demand of $725 \mathrm{~kW}$, and an initial load demand of $186 \mathrm{~kW}$. Figure 4 shows the demand for monthly electricity bills at low, moderate and maximum hours .Low, medium and peak hours in the summer hours from 23:00 to 7:00, 7:00 to 19:00 and 19:00 to 23:00, and in the winter hours from 21:00 to 5:00, 5:00 to 17:00, and 17:00-21:00. The coefficient of charge we considered was 0.25 .

\section{1-2 System component information}

The use of generator diesel especially in systems independent of the network is essential to ensure the continuity of supply. Also, the storage unit is used to balance electricity generation and power consumption. However, in the region with access to the network, diesel generator and battery storage can be removed. Technical characteristics of system components are presented in Table 1. It is to be mentioned that in practice the real constraints are determined by investors regarding the required investments and the cost of generating electricity, access to equipment, required fields, government incentives and technical issues.

\section{2-Financial data}

Table 2 shows the costs of the system components. According to the energy price liberalization program in Iran, the price program of the energy carriers must reach $75 \%$ of its export price, which means electricity and gas prices would be $7.5 / \mathrm{kWh}$ and $24 / \mathrm{L}$ Moreover, given the government's incentive policies, the price of electricity sales to the network is about $\$ 0.2 / \mathrm{kWh}$ for wind and $\$ 0.3 / \mathrm{kWh}$ for solar power production (SUNA organization). The length of the project life and the real interest rate is 20 years and 10.\%

Table 2: Specifications for the type and cost of system components

\begin{tabular}{|c|c|c|c|c|}
\hline Component & Useful life & $\begin{array}{c}\text { Initial } \\
\text { cost(kw\dollar) }\end{array}$ & $\begin{array}{c}\text { Replacement } \\
\text { cost(kw } \backslash \text { dollar) }\end{array}$ & $\begin{array}{c}\text { Maintenance } \\
\text { costs(kw } \backslash \text { dollar) }\end{array}$ \\
\hline diesel generator & $15000 \mathrm{H}$ & 15200 & 15200 & 0.8 \\
\hline Photovoltaic panel & 25 year & 16500 & 16500 & 10 \\
\hline Biomass & $15000 \mathrm{H}$ & 18400 & 18400 & 10 \\
\hline Wind Turbine & 30 year & 22500 & 22500 & 10 \\
\hline Battery & 4 year & 150 & 150 & 20 \\
\hline Battery Convertor & 30 year & 4250 & 4250 & 40 \\
\hline
\end{tabular}




\section{2- Simulation process}

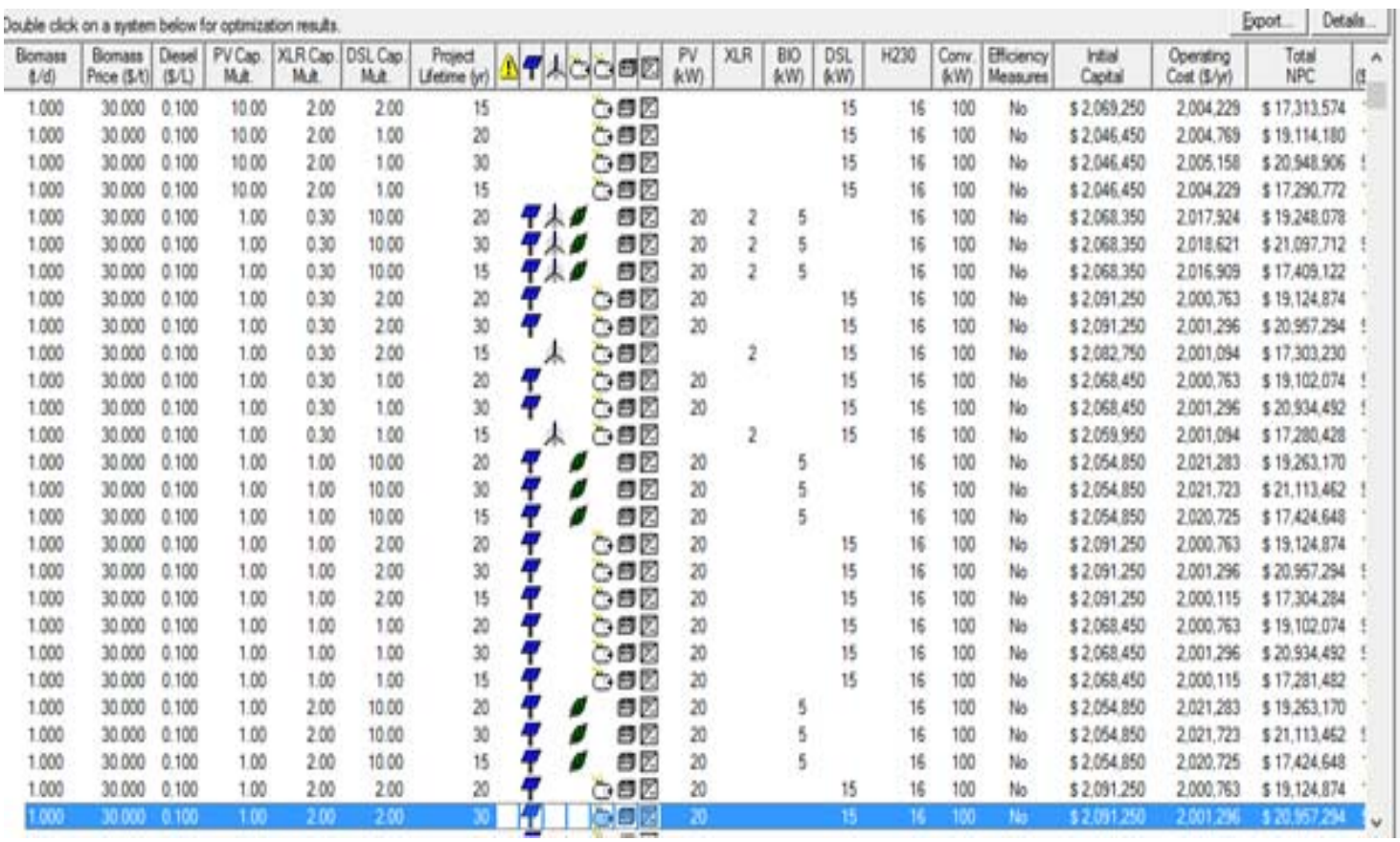

Figure 5: General simulation results

\section{2-1 Output of photovoltaic panels}

Solar cells produced the highest production between 10 and 14, and in January, February, March, and especially November, the solar cells had the highest production in the same hours. With regard to simulation results and as shown in Fig. 6, photovoltaic cells have a large role in load supply, since the capacity of these cells in this limited study is possible due to the load type. but since there is a low load in this study and the number of production resources is large, there is no problem in terms of production shortage and more economical resources will have the highest production here solar cells and then wind turbines are operated. It is evident that the investment costs of power electronic devices such as inventor with respect to the high costs of it are higher than the other ones.

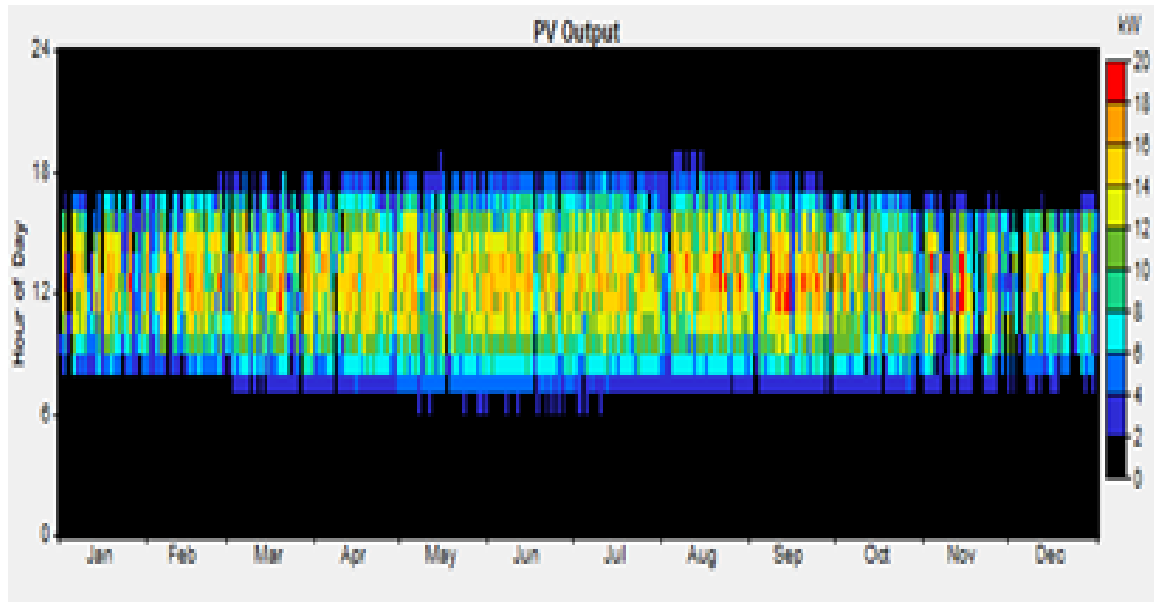

Figure 6: Output of photovoltaic panels

\section{1-1. Biomass Generator Output and Diesel Generator}

This state of the biomass generator between 12:00 and 20:00, according to peak load, has the highest production and is off for the rest of the hours. The reason is that biomass production requires the operator and may not be economically feasible. But, other technical and economic parameters also affect biomass performance. In this scenario, diesel generators have little production, due to the high costs of maintenance and surely the initial investment (in this article) and also in terms of the environment (which Homer software is sensitive to), during a few hours a day from day to day is located. Figure $7(a, b)$. 

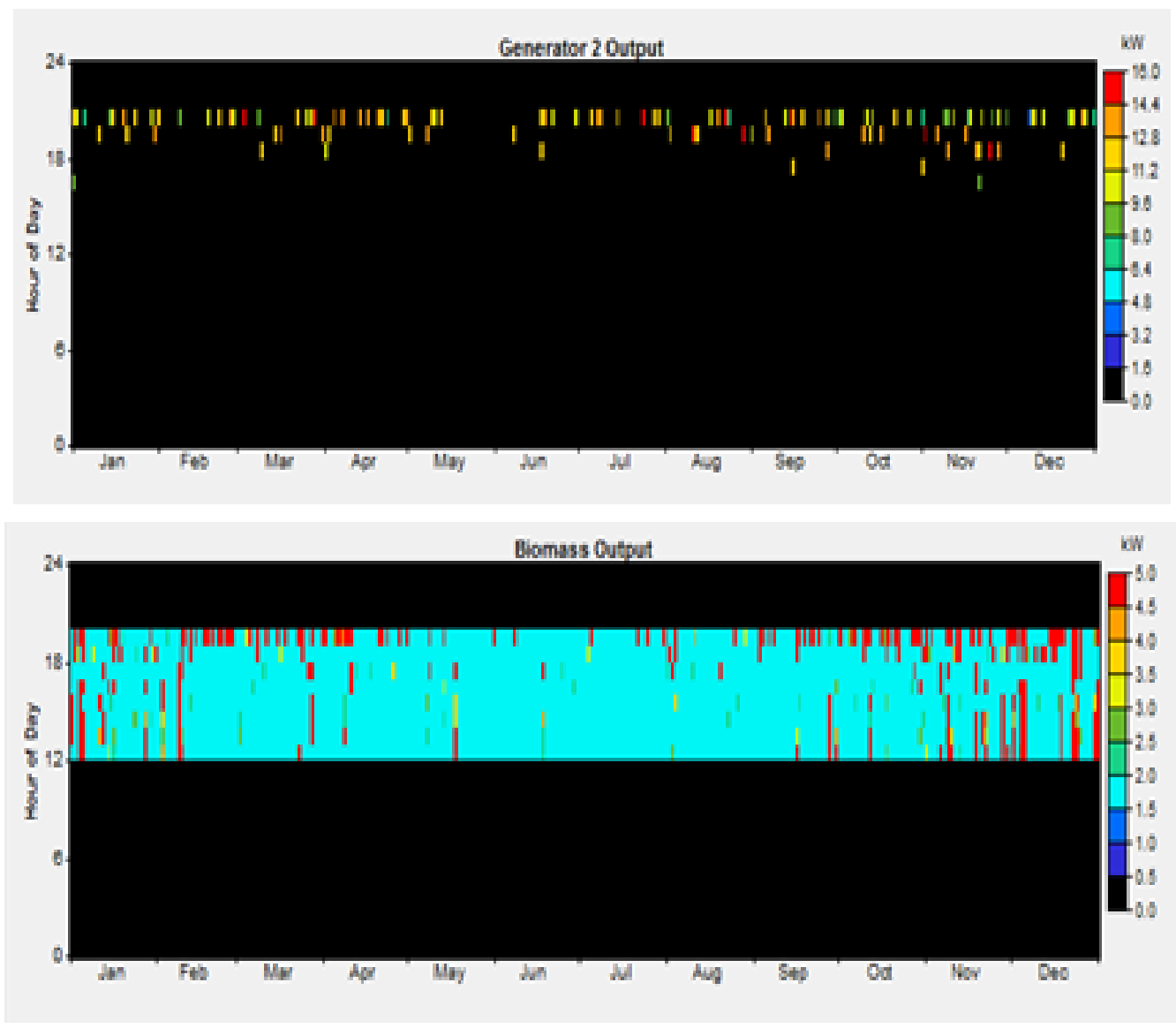

Figure 7: Biomass Output (A) - Output of Diesel Generator (B)

2- Analysis of simulation results

According to the results of simulation using the study load and the costs and network used, the combined power plants which are more suitable for load demand are analyzed as follows:

\subsection{Effect of the price of solar panel investment in wind turbine:}

According to Figure 8, the prices for wind turbines, solar panels, diesel generators, biomass, and battery life are considered to be the actual current price of the equipment. In today's conditions and prices, the best option for supplying electricity to domestic customers with the load curve examined is the use of a photovoltaic hybrid power plant, battery and biomass.

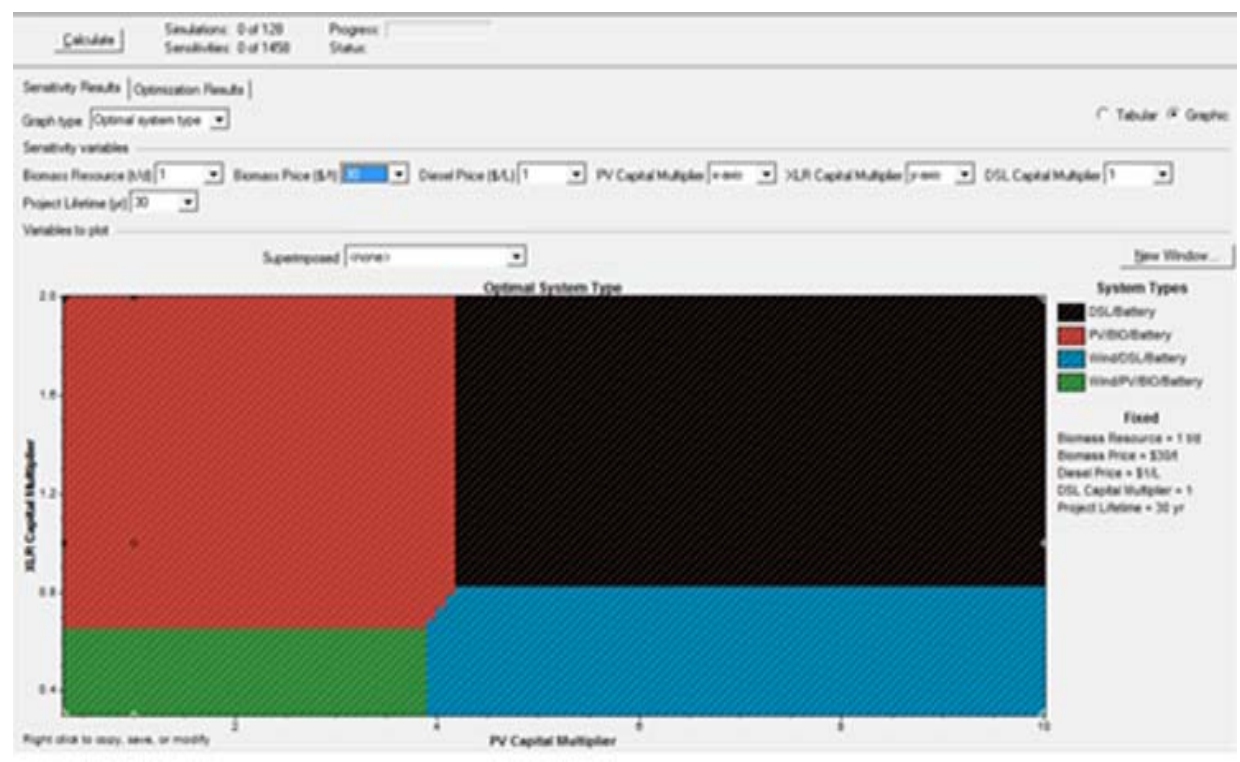

Figure 8: Impact of solar panel price relative to wind turbine 


\subsection{Impact of Diesel Investment Price Changes versus Wind Turbine:}

In figure 9, prices for wind turbines, solar panels, diesel generators, biomass and battery life are considered to be the real price for the current equipment. In today's conditions and prices, the best option for supplying electricity to domestic customers with the load curve examined is the use of a photovoltaic, battery, and diesel power plant.

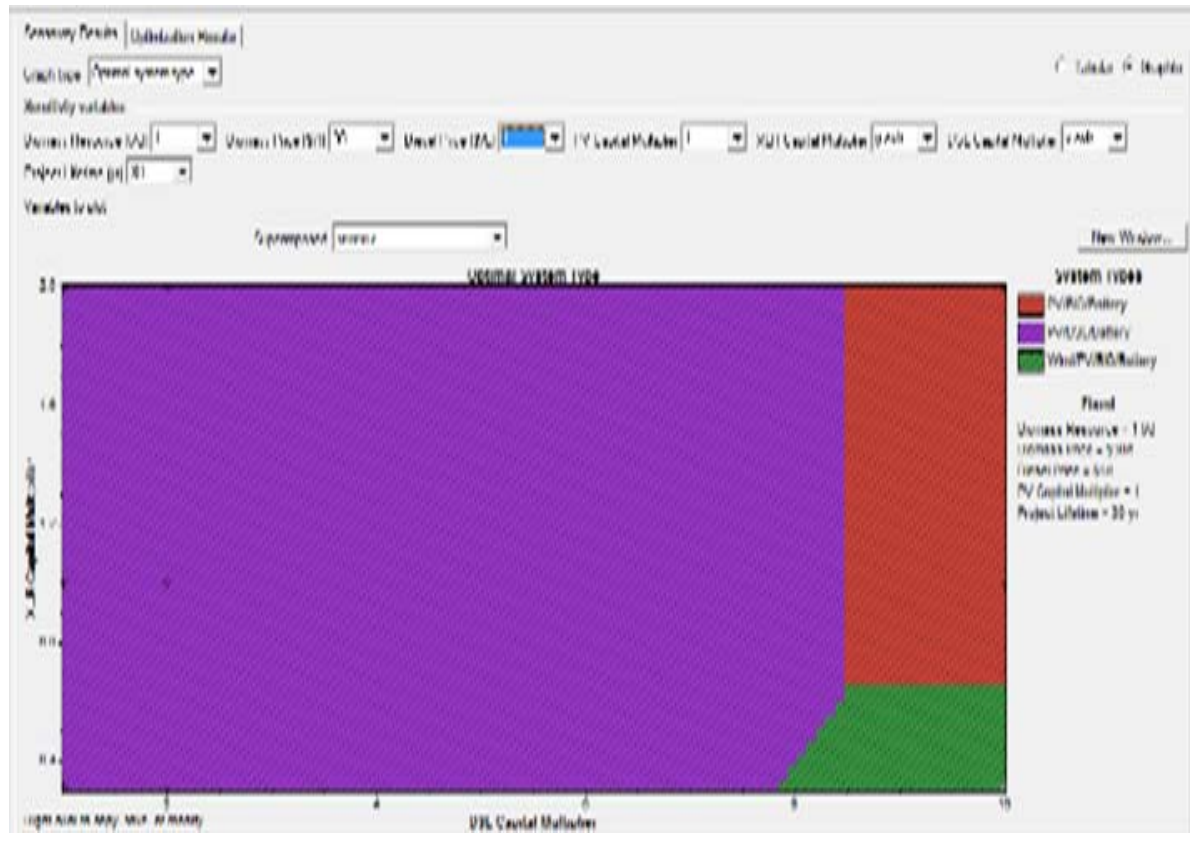

Figure 9: Impact of Diesel Investment on Wind Turbines

\section{2-3. the effect of biomass price change over diesel prices:}

According to Figure 10, prices for wind turbines, solar panels, diesel generators, biomass and battery life are considered to be the real price for the current equipment. In today's conditions and prices, the best option for supplying electricity to domestic customers with the load curve examined is the use of a photovoltaic, battery, and diesel power plant

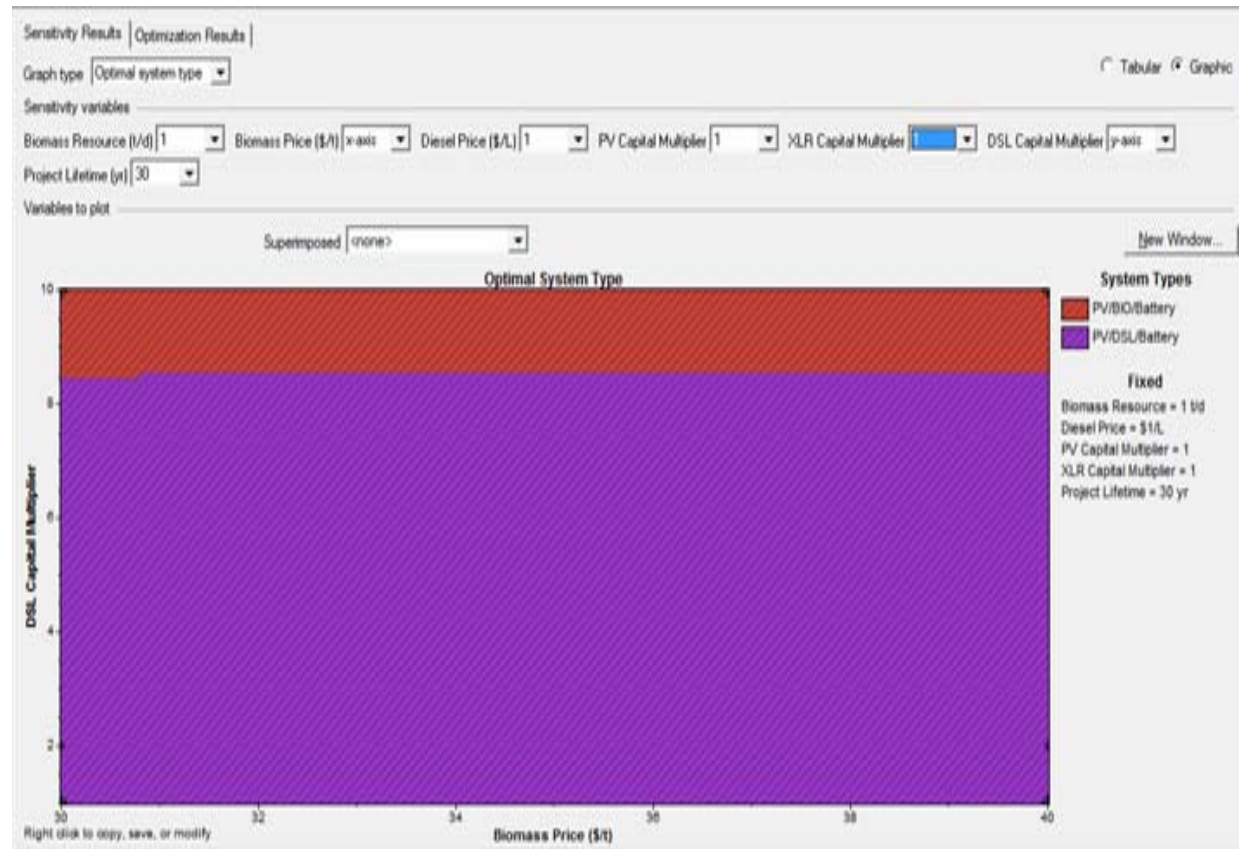

Figure 10: The effects of biomass prices on diesel costs 


\section{Conclusion}

In this paper, a hybrid energy system is designed to meet the needs of power of iran.a number of settings outside the network and on the diesel generator network, wind turbine, biomass panel, biomass and battery storage were investigated. This can be concluded as follows:

The results show that the optimal recruitment in hybrid systems design has a significant impact in reducing costs and making the project economical. It is clear from the results that for home loads, due to the existence of peak times, the use of the biomass plant is conomical, although other technical and economic parameters must be considered. The carbon emissions tax could be a viable policy to encourage investment in large renewable energy projects.

\section{Reference}

[1] The International Energy Agency is on the Internet http://www.iea.org/statistics

[2] A survey of global energy by the British Petroleum Corporation .2014, by the address http://www.bp.com/statisticalreview\#BPstats

[3] Iran Renewable Energy Organization (suna, Tehran, Iran) http://research.suna.org.ir/en/home:

[4] Prasetyaningsari I, Setiawan A, Setiawan AA. Design optimization of solar powered aeration system for fish pond in Sleman Regency, Yogyakarta by HOMER software. Energy Proc 2013;32:90-8.

[5] Kumar US, Manoharan PS. Economic analysis of hybrid power systems (PV/ diesel) in different climatic zones of Tamil Nadu. Energy Convers Manage 2014;80:469-76.

[6] Elghitani, F., \& Zhuang, W. (2018). Aggregating a large number of residential appliances for demand response applications. IEEE Transactions on Smart Grid, 9(5), 5092-5100.

[7] Homer's Guide to Internet Address : $<$ http://www.homerenergy.com/pdf/ HOMERHelpManual.pdf 